\title{
REDESAIN INTERIOR RUMAH DETENSI IMIGRASI JAKARTA
}

\author{
Dandy Miantino Utomo \& Setya Budi Astanto* \\ Program Studi S1 Desain Interior ISI Yogyakarta
}

\begin{abstract}
ABSTRAK
Kejahatan Imigrasi di Indonesia mengalami peningkatan yang sangat signifikan. Oleh sebab itu Direktorat Jenderal Imigrasi Jakarta menambahkan penjara khusus yang hanya menahan para pelaku kejahatan imigrasi seperti paspor illegal, visa illegal, dan penyelundupan barang illegal. Penjara khusus ini dinamakan Rumah Detensi yang dimana penjara ini merupakan penjara sementara untuk menahan pelaku kejahatan imigrasi dengan sistem penjara apabila di nyatakan bersalah akan di deportasi ataupun di pindahkan ke penjara umum, banyak Rumah Detensi yang ada di Indonesia yang tidak layak huni dan tidak sesuai dengan hak asasi manusia mereka. Oleh karena itu perancangan interior Rumah Detensi mengambil tema Human Rights for Modern Humanisme Design. Tema ini bertujuan untuk menciptakan desain yang mengacu pada hak asasi manusia sehingga mereka mendapatkan hak yang sesuai. Gaya yang akan dipakai didalam desain Rumah Detensi Imigrasi ini adalah modern loft dengan menggunakan gaya ini di harapkan bisa mengatasi masalah - masalah yang ada di dalam rumah detensi. Salah satu yang unik di dalam desain Rumah Detensi ini adalah penggunaan warna baker miller pink di dalam ruang isolasi diharapkan mampu mengurangi tingkat agresif tahanan.
\end{abstract}

Kata kunci: Rumah Detensi, Imigrasi, Hak Asasi Manusia, Penjara KhususKata kunci: desain kolaboratif, produk lokal, design thinking

\section{PENDAHULUAN}

Rumah Detensi adalah unit pelaksana teknis yang menjalankan fungsi keimigrasian sebagai tempat penampungan sementara bagi orang asing yang melanggar undang-undang Imigrasi. Rumah Detensi sering disingkat dengan nama lain yaitu Rudenim dan orang asing yang ada di rudenim disebut dengan nama Deteni. Rudenim dibangun karena meningkatnya lalu lintas orang, baik yang keluar maupun yang masuk ke Indonesia, sehingga berpotensi timbulnya permasalahan keimigrasian dan memerlukan upaya penindakan bagi orang asing yang melanggar ketentuan undang - undang di Indonesia. Salah satu cara untuk mengefektifkan dan mengefisienkan penindakan tersebut diperlukan adanya sarana dan prasarana pendukung seperti rudenim. Rumah Detensi adalah bagian dari Direktorat Jenderal Imigrasi, yaitu sebuah struktur dari Kementerian Hukum dan Hak Asasi Manusia Indonesia yang memiliki tugas pokok penindakan, pengisolasian, dan pemulangan atau deportasi warga negara asing yang melanggar undang - undang keimigrasian (Pedoman Ham, 2011). Seperti misalnya visa illegal, passport illegal, narkoba, penjualan organ tubuh, dan juga penyelundupan barang illegal. Indonesia memiliki 13 rumah detensi yang tersebar di seluruh kota - kota besar yang ada di Indonesia, salah satunya berlokasi di jalan H. R. Rasuna Said Kav.X - 6, Kuningan, Kota Jakarta Selatan, Daerah Khusus Ibukota Jakarta.

Semakin banyaknya pelanggaran - pelanggaran imigrasi di Indonesia kantor pusat direktorat jenderal imigrasi perlu memiliki penjara khusus sendiri yang disebut rumah detensi dengan tingkat keamanan dan kenyamanan serta hak asasi manusia yang terjamin. Banyaknya pelanggaran imigrasi di Jakarta mengakibatkan rumah detensi yang ada tidak dapat menampung para deteni lagi, rumah detensi di dalam kantor pusat direktorat jenderal imigrasi ini bertujuan untuk mempermudah pengawasan terhadap tahanan tetapi juga perlu pengamanan yang ketat untuk menahan para pelaku penyelundupan barang ilegal dan juga menahan warga negara asing yang mempunyai paspor atau visa ilegal, tidak hanya penjara bagi tahanan ada juga tempat penyimpanan barang bukti ilegal, ruang introgasi, dan juga kantor penjaranya.

Melihat fenomena ini, maka perencanaan dan perancangan sangatlah memegang peranan penting untuk membuat rumah detensi yang benar - benar sesuai dengan kebutuhan, fungsi, aktifitas, 
keamanan, serta pekerjaan. Perancangan mempertimbangkan desain - desain modern, furniture yang multifungsi, teknologi yang baru dan mengacu pada hak asasi manusia sebagai solusi untuk mengatasi masalah - masalah yang ada di dalam rumah detensi seperti kelayakan dan sisi humanisme.

Menurut Schauss $(1979,1981,1985)$, dalam studi pendahuluannya menunjukkan bahwa subyek secara lebih konsisten terlihat lebih rileks ketika melihat papan yang diwarna pink. Sebuah eksperimen kecil terhadap dirinya sendiri juga memperlihatkan bahwa warna pink dapat menurunkan detak jantung, denyut nadi, tekanan darah, dan pernafasan, setelah Schauss melakukan olahraga keras. Ia pun ingin menguji pengaruh warna pink lebih jauh lagi terhadap perilaku seseorang, dalam hal ini adalah tingkat agresivitasnya. Selama beberapa tahun kemudian ia mengadakan percobaan di 3 penjara AL AS, 2 penjara daerah California, dan 2 rumah sakit jiwa. Selanjutnya pengujian campuran warna Baker-Miller Pink (R: 255, G: 145, B:175) dilakukan dengan mengecat sebuah sel seluruhnya kecuali lantai yang dibiarkan coklat polos. Hasilnya, potensi perilaku kasar atau agresif yang dimiliki tahanan berkurang hanyak dalam waktu 15 menit, dan efek tersebut tetap bertahan 30 menit setelah tahanan dikeluarkan dari sel pink tersebut.

\section{METODE PERANCANGAN}

Metode perancangan yang digunakan adalah metode analitis (analitical method), yang mengacu pada metodologi desain (Jones, 1971) sebagai formulasi dari apa yang dinamakan "berpikir sebelum menggambar" (thinking before drawing). Dalam metode analitis ini hasil rancangan akan sangat dipengaruhi oleh proses yang dilakukan sebelumnya. Proses tersebut meliputi penetapan masalah, pendataan lapangan, literature, tipologi, analisis pemrograman, sintesis, skematik desain, penyusunan konsep dan pewujudan desain

Metode perancangan analitis ini ada beberapa proses desain yang harus dilakukan. Pertama menentukan problem (masalah), menemukan masalah-masalah yang ada didalam Rumah Detensi Imigrasi. Permasalahan disini akan selalu dikaitkan dengan faktor manusia sebagai penggunanya, yang disadari maupun yang tidak. Untuk kendala yang dapat disadari oleh penggunanya, maka pengguna itu sendiri yang menetapkan permasalahan. Desainer sebagai orang yang menguasai teori dan aplikasi perancangan akan dapat memiliki kepekaan untuk menemukan kendala-kendala yang tidak disadari oleh penggunanya tersebut dan untuk menemukan permasalahan permasalahan yang ditemukan saat survey langsung ke lokasi.

Langkah kedua yang harus dilakukan adalah pendataan, pendataan perlu dilakukan karena untuk mengetahui informasi - informasi yang ada di rumah detensi. Data Fisik seperti unsur pembentuk, pengisi ruang, ukuran-ukuran, material, kondisi udara, suara, cahaya serta kondisi lapangan dan data non fisik seperti lingkungan sosial, ekonomi, budaya, psikologis, keinginan klien, dan kebutuhan pengguna ruang. Data yang juga sangat penting adalah data literature. Data literatur disusun berdasarkan tingkat kebutuhannya untuk menilai hasil pendataan fisik dan non fisik. Literatur yang spesifik yang berkaitan dengan permasalahan utama perancangan Rumah Detensi Imigrasi penting dicantumkan secara mendetail dalam proses pendataan. Data berikutnya adalah data tipologi yaitu berupa data lapangan yang diambil dari lokasi berbeda namun memiliki tipe yang sama dengan data lapangan yang menjadi objek perancangan. Data tipologi ini berfungsi sebagai pembanding atas data lapangan dan di samping itu data tipologi juga dapat digunakan sebagai tolok ukur untuk membantu kasus - kasus perancangan yang sulit dicari literaturnya.

Ketiga, adalah analisis programming. Tahap ini merupakan tahap pemrograman, yaitu membuat program - program kebutuhan desain berdasarkan hasil-hasil analisis. Kelengkapan data dihimpun agar hasil analisis semakin tuntas sehingga program - program kebutuhan yang dimunculkan menjadi acuan yang dapat dipenuhi. Langkah keempat, berupa sintesis hasil analisis program merupakan dasar dalam menarik sintesis berupa simpulan- simpulan awal yang dapat dijadikan alternatif-alternatif arah perancangan. Kelima, menyusun skematik dan konsep desain. Pada tahapan ini proses perancangan skema - skema pemecahan masalah perancangan atau skematik desain dan disisi lain mulai diformulasikan menjadi konsep desain yang dijadikan pengikat arah perancangan. Skematik desain dan konsep dasar desain ini dievaluasi sebelum dikembangkan lebih lanjut menjadi sebuah desain berupa gambar-gambar penyajian. Langkah terakhir adalah menyusun hasil desain dan feedback. Hasil desain ini dievaluasi berdasarkan program-program yang ditetapkan dalam analisis pemrograman melalui sebuah proses umpan balik (feed back). 


\section{HASIL DAN PEMBAHASAN}

Konsep Desain yang dipakai untuk desain rumah detensi ini adalah Technology Isolation Room. Konsep ini digunakan karena penjara imigrasi merupakan penjara sementara yang menahan para pelaku kejahatan imigrasi untuk memberikan mindset kepada mereka bahwa semua ruang akan di pantau langsung dan tidak ada celah buat melarikan diri. Melalui penerapan konsep technology isolation room, desain dibuat menggunakan technologi baru yang berbeda dari rumah tahanan lainnya yang ada di Indonesia. Konsep rumah detensi ini menerapkan juga sifat ruang isolasi itu sendiri seperti tertutup akan dunia luar dan juga keamanan yang sangat ketat untuk para deteni maupun para pekerja.

Tema mengangkat Human Rights for Modern Humanisme Design adalah desain yang mengedepankan desain - desain simple, bersih, fungsional, memiliki teknologi yang canggih, sesuai standar internasional, lebih manusiawi dan selalu mengikuti perkembangan zaman. Human Right yang dimaksud ini adalah desain yang mengedepankan hak asasi manusia sebagai acuan dalam mengatasi masalah - masalah yang ada di rumah detensi imigrasi ini. Sentuhan modern humanisme diharapkan mampu membuat desain - desain yang lebih manusiawi dan juga aman, tidak selalu mementingkan estetis dalam suatu ruang. Modern Loft diterapkan di dalam perencanaan dan perancangan interior, gaya ini menjadi salah satu solusi untuk mengatasi keinginan klien dan juga mengatasi permasalahan - permasalahan yang ada.

Material yang dipakai menggunakan bahan yang aman untuk para tahanan maupun karyawan contoh nya menggunakan concrete, besi, stainless steel, vinyl, dan juga glasswool. Warna yang dipakai menggunakan warna monokrom, coklat, dan juga warna yang bisa digunakan untuk ruang isolasi yaitu baker miller pink. Warna baker miller pink ini bisa mengatasi masalah - masalah yang terjadi di dalam rumah detensi yaitu untuk mengurangi agresi yang dimiliki tahanan hanya dalam waktu 15 menit.

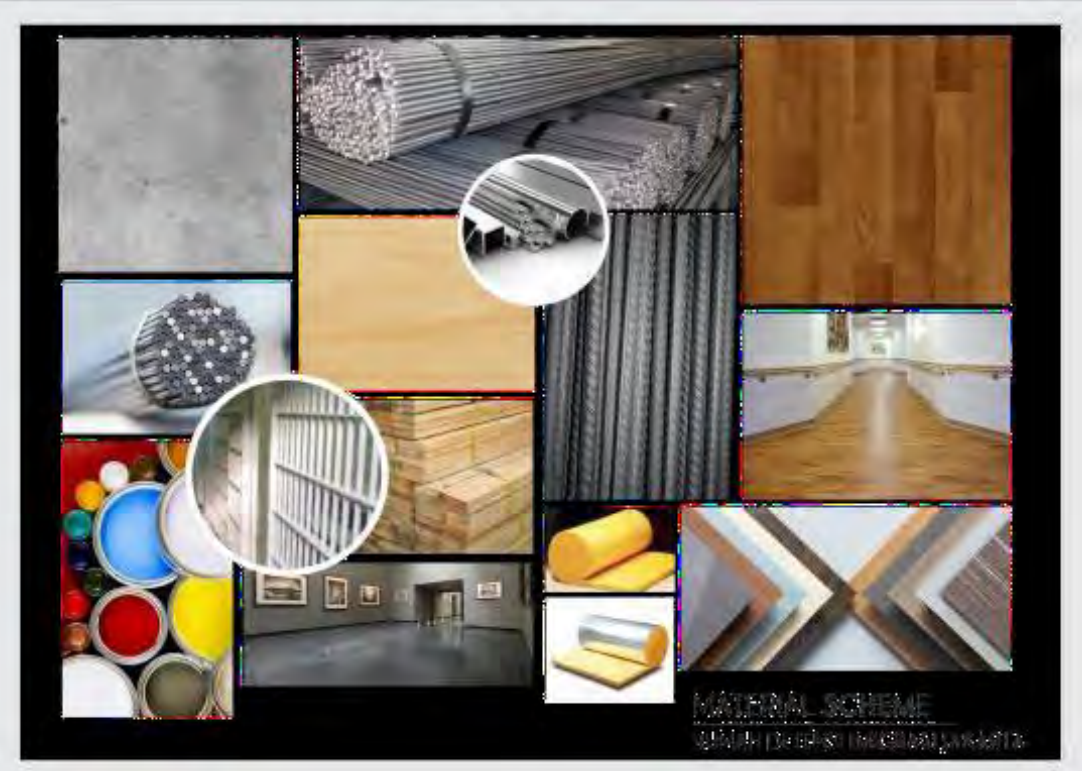

Gambar 1 Moodboard Skema Warna (Miantino \& Astanto, 2017) 


\title{
Concept Colour Scheme
}

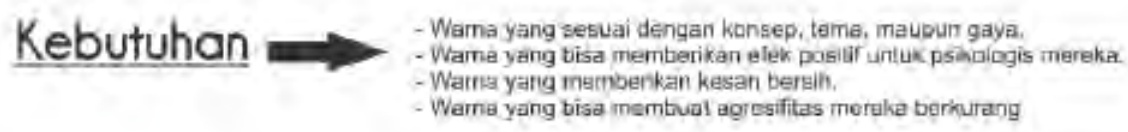

\author{
Wama Dominan \\ PUTH wama yano positis, netral \\ dan bersth. \\ COKLAT wama yano positi, hangat \\ dan alami \\ ABU - ABU wanc yano posilit, netral
}

\section{Warna Pendukung}

HITAM wama yano kuat, dominon dan modern. BAKER MILLER PINK warna yono kuat. dominon dan memberkan effek psinolools.

Gambar 2 Skema Warna (Miantino \& Astanto, 2017)

Warna - warna yang digunakan dalam perancangan interior rumah detensi ini adalah warna - warna yang banyak memberikan effek positif untuk psikologis para deteni dikarenakan untuk memberikan kenyamanan ataupun kebutuhan mereka dan untuk terwujudnya Hak Asasi Manusia para deteni itu sendiri. Warna - warna ini diambil dikarenakan beberapa effek positif warna tersebut baik untuk psikologis para deteni

Warna-warna tersebut di gambar 2 diterapkan pada area sirkulasi yang menghubungkan antara ruang monitor, ruang manajer, ruang tamu, ruang istirahat dan juga area para tahanan. Area karyawan dibatasi dengan dua pintu besi penjara antara area kerja para pegawai rumah detensi dengan area tempat para tahanan. Pada area ini diberikan keluasan karena apabila memasukkan ataupun mengeluarkan tahanan melewati area ini. Material yang digunakan di dalam area untuk lantai menggunakan concrete polished berwarna abu - abu muda, dinding juga menggunakan concrete polished berwarna abu - abu tua, kaca tamperglass, dan juga untuk plafon menggunakan stainless steel yang berbentuk persegi panjang.

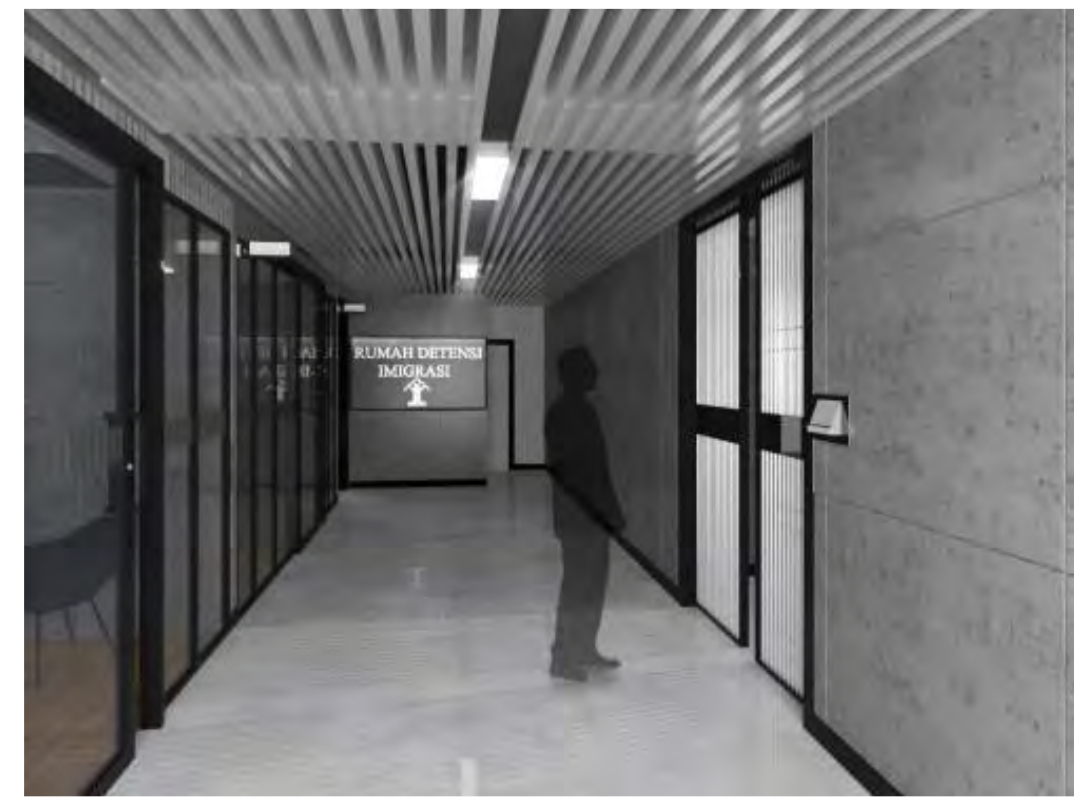

Gambar 3 Area Sirkulasi (Miantino \& Astanto, 2017) 


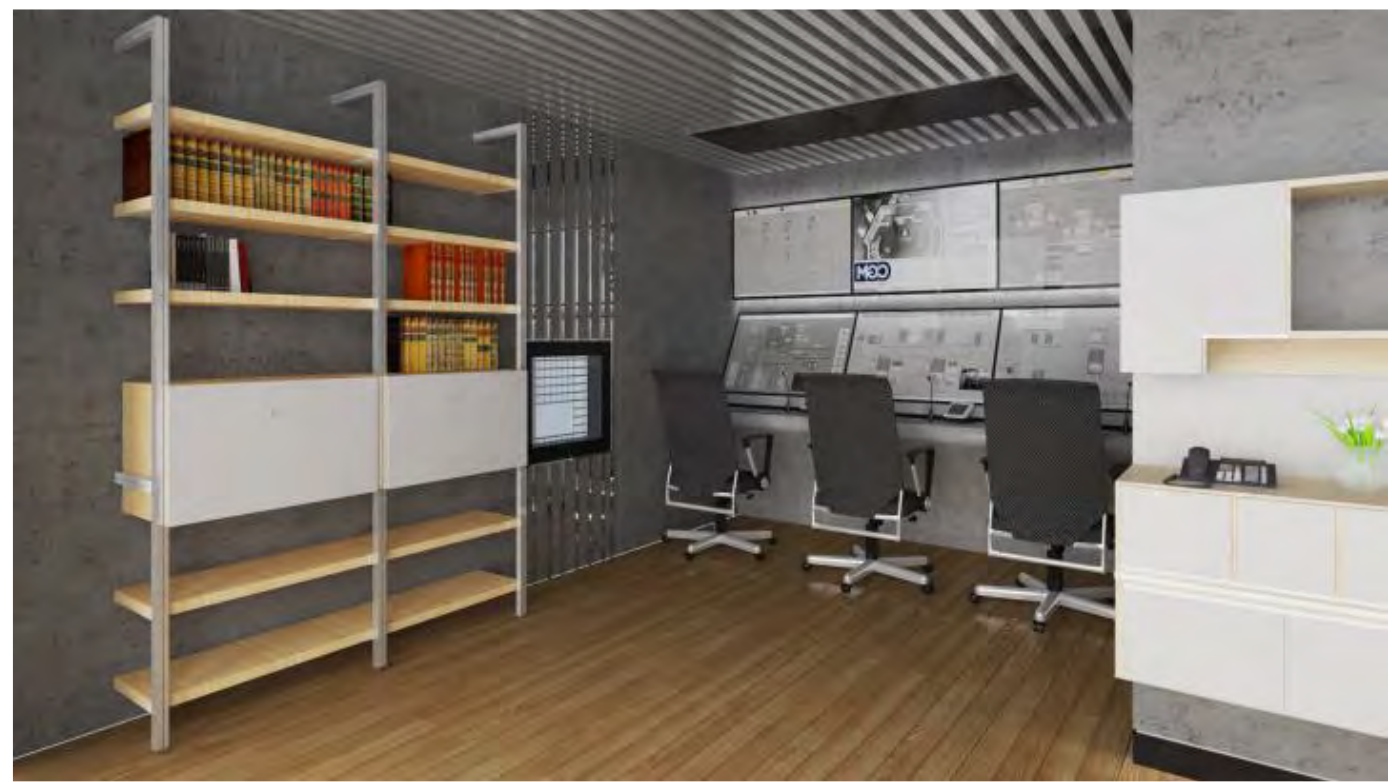

Gambar 4 Ruang Monitor (Miantino \& Astanto, 2017)

Area ruang monitor ini digunakan karyawan rumah detensi imigrasi untuk memonitor para tahanan yang ada di rumah detensi. Bahan material yang dipakai adalah vinyl untuk lantai, dinding menggunakan concrete polished, dan plafon stainless steel.

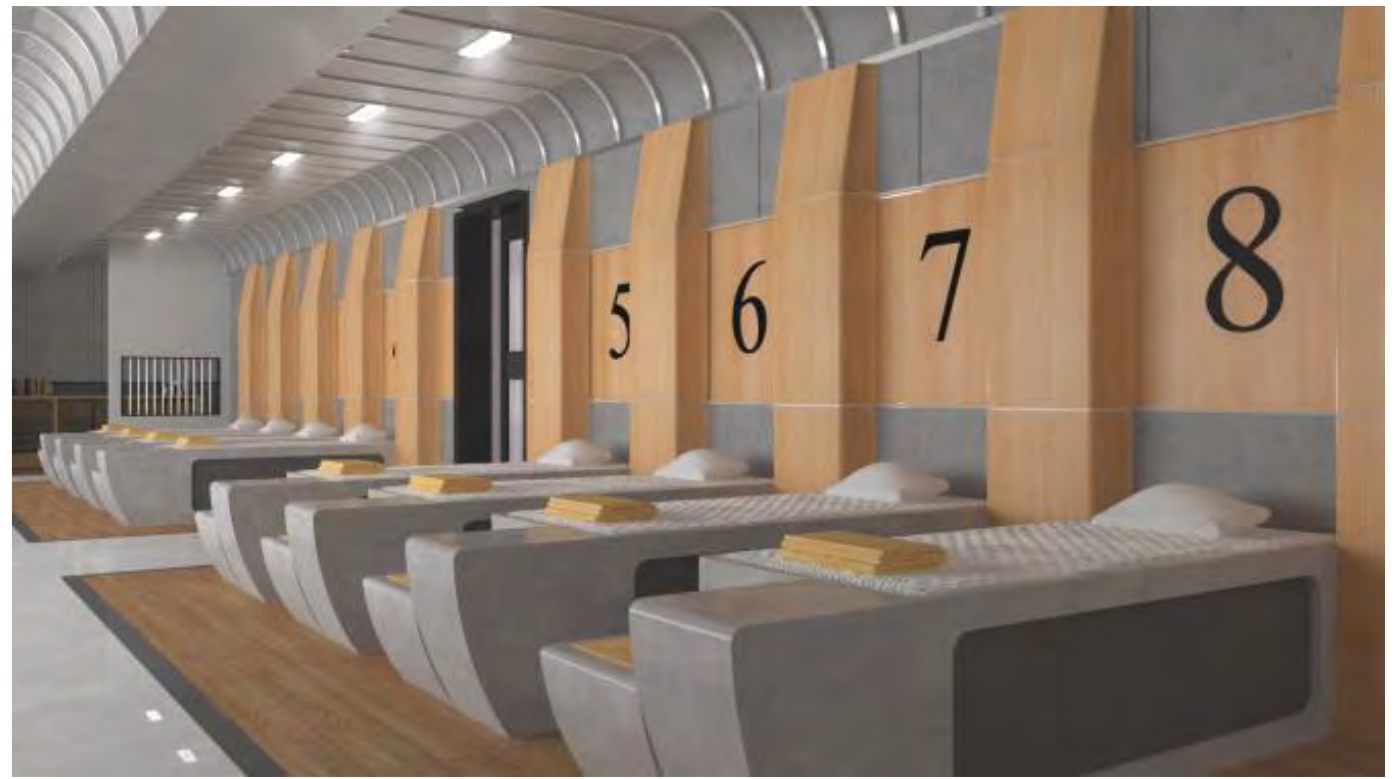

Gambar 5 Ruang Tahanan (Miantino \& Astanto, 2017)

Area ini adalah ruang yang hanya di pakai oleh para tahanan rumah detensi sistem di dalam ruang tahanan ini adalah seperti barak yang di dalamnya ada tempat tidur berjejer dan tidak ada pembatas antar para tahanan.

Warna baker miller pink adalah warna khusus yang hanya digunakan pada area ruang isolasi saja. Warna baker miller pink memberikan effek positif yaitu meredakan agresifitas tahanan hanya dalam waktu 15 menit, warna ini telah dipakai didalam penjara - penjara internasional yang ada di luar negeri contohnya penjara Santa Clara County, San Bernardino Youth Clinic, Bold Tendencies di Inggris, dan rumah sakit psikiater di California. Warna ini dipakai pada ruang isolasi karena banyaknya keluhan - keluhan yang ada di rumah detensi yang sudah ada dengan harapan warna ini mampu menjadi solusi di dalam rumah detensi ini. 


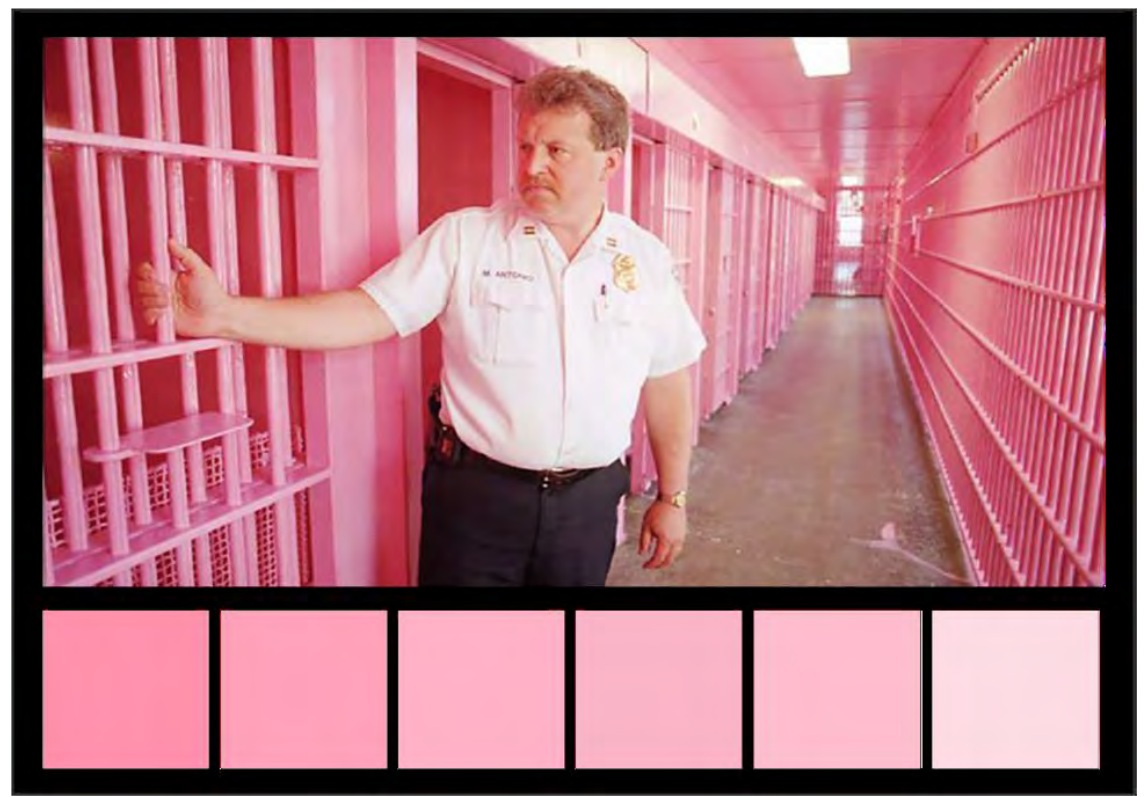

Gambar 6 Skema Baker Miller Pink (Schauss, 1985)

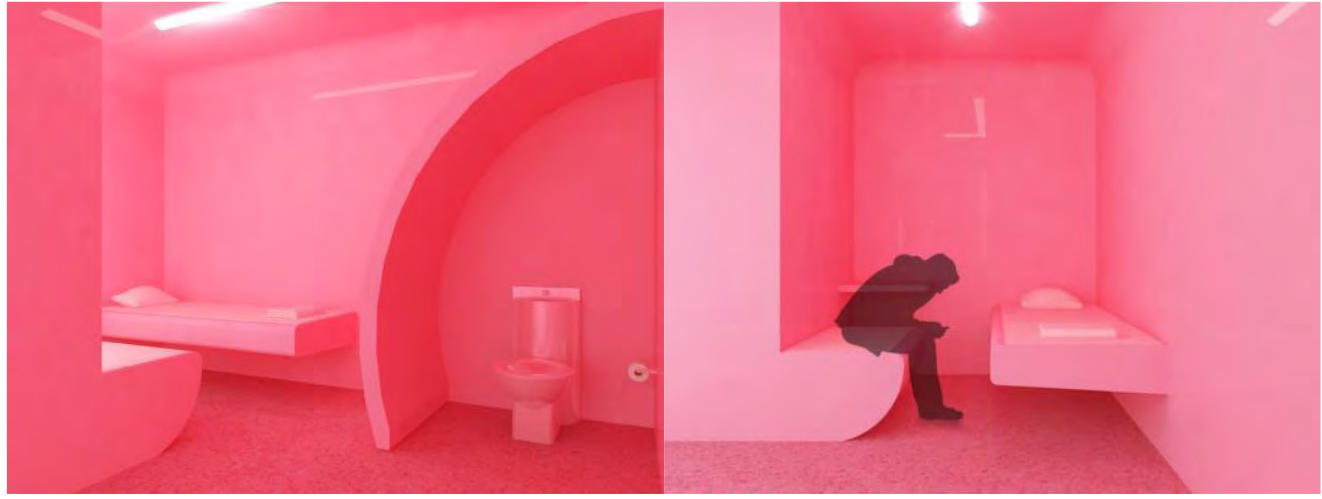

Gambar 7 Desain Ruang Isolasi (Miantino \& Astanto, 2017)

Ruang isolasi dirancang adalah ruang khusus untuk tahanan yang bermasalah dan hanya dipakai apabila tahanan mengamuk di dalam tahanan ataupun para tahanan deteni berkelahi antar sesama tahanan lain. Warna yang dipakai di dalam ruang isolasi ini mengadopsi baker miller pink. Warna ini diharapkan bisa mengurangi tingkat angresi hanya dalam waktu 15 menit di dalam ruang isolasi.

\section{KESIMPULAN}

Rancangan interior rumah detensi sangat mempertimbangkan segi keamanan, kenyamanan, maupun dari segi hak asasi manusia. Kelayakan menjadi prioritas utama untuk memenuhi hak asasi manusia para tahanan. Meningkatkan keamanan dan sistem pengawasan cctv yang ada di rumah detensi untuk mengatasi beberapa masalah penerobosan penjara rumah detensi. Konsep Technology Isolation Room dengan mengaplikasikan teknologi - teknologi baru yang dipakai yaitu dari segi elektronik, warna, maupun bentuk furniture dengan ruangan yang benar benar tertutup dari dunia luar. Sifat ruang isolasi memberikan mindset kepada mereka bahwa keamanan yang ada di rumah detensi ini sangat ketat dan tidak ada jalan untuk melarikan diri, dengan konsep ini diharapkan rumah detensi ini mampu menjadi penjara yang aman, nyaman, dan selalu memberikan hak - hak wajib untuk deteni. 


\section{DAFTAR PUSTAKA}

Pedoman HAM bagi Petugas Rumah Detensi. 2011. Jakarta: Badan Penelitian dan Pengembangan HAM Kementerian Hukum dan HAM RI.

Schauss, Alexander G. 1979. "Tranquilizing effect of color reduces aggressive behavior and potential violence" in Journal of Orthomolecular Psychiatry, Vol. 8, p. 218-220.

Schauss, Alexander G. 1981. "Application of behavioral photobiology to human aggression: Baker- Miller pink" in The International Journal for Biosocial Research, Vol. 2, p. 25- 27.

Schauss, Alexander G. 1985. "The Physiological Effect of Color on the Suppression of Human Aggression: Research on Baker Miller Pink" in The International Journal for Biosocial Research, Vol. 2, p. 5564. 